\title{
LINGUISTICS ANALYSIS: FIGURATIVE LANGUAGE USED IN ROBERT FROST'S POEM
}

\author{
Rida Fahas ${ }^{1}$, Rizqi Husaini ${ }^{2}$, Puput Jianggimahastu L.S. ${ }^{3}$, Dedy Richi R. ${ }^{4}$ \\ Universitas PGRI Madiun \\ rida.fahas@unipma.ac.id ${ }^{1}$ \\ rizqi.husaini@unipma.ac.id ${ }^{2}$ \\ puput.jiang@unipma.ac.id ${ }^{3}$ \\ Dedy.rr@unipma.ac.id ${ }^{4}$
}

\begin{abstract}
This research aims to find out the most dominant figurative language that used in poems of Robert Frost.This study includes to qualitative research with an objective approach to analyze the poems of Robert Frost ${ }^{\text {e's }}$ selected poems. The sources of data is obtained in this study by looking for books and internet that contains about literature and poetry. The writer uses note taking method in the collection of data that is by reading, writing and looking for poems of Robert Frost's selected poems related to the formulation of the problems. The technique of analysis of the data is by reading, identifying, understanding, finding, and making conclusion every poems which is analyzed from the poems of Robert Froste"s selected poems related to the formulation of the problems in the study. The results of the study shows that the most dominant figurative language in the selected poems are two Metaphor, eleven personification, four symbol, three hyperbole, and one repetition. So, it can be coclude that this selected poems are dominate by "Personification".
\end{abstract}

Keywords: figurative language, Robert Frost, Poem

\section{INTRODUCTION}

Poetry is one of literary works that is more expressive (uses figurative language) and connotative meaning (use unliteral meaning) rather than other literary works like prose and drama. Frost (in Arp, 2012:72) states that "Poetry provides the one permissible way of saying one thing and meaning another". According to Perrine in
Siswantoro (2010: 23) poetry is said to be the most condensed and concentrated form of literature.

According to Alfiah and Santosa (2009: 27), figurative language is the use language style by the poet to describe, issue, and express feelings and thoughts in writing poetry. It is crucial to get the poetic meaning of poem. There are figuratives language make poem more interesting because languge that used in the poem is parable, so 
the reader have to interpret for the meaning of what is written in the poem. Also it makes the poem have beautiful language and full of imaginative, inanimate objects are made as if it were alive and vice versa (for example; the pencil danced on the paper, you are as beautiful as a rising sun.).

Figurative language is using words to imply another meaning. In the other hand, figurative language is language style that used by the poet to describe and expresses his feeling. Welleck (in Walidain, 2012: 14) states that "A poet is a literary artist and language is the material of his painting". It means that language is important for a poet to create a poem. Besides, Perrine (in Arp, 2012:73) states that "figurative language is any way of saying something other than the ordinary way". In his perception, figurative language consists of twelve types, those are: simile, metaphor, personification, apostrophe, synecdoche, metonymy, symbol, allegory, paradox, hyperbole, understatement, and irony. According to Keraf $(2007 ; 138)$ there are many kinds of figurative language, such as simile, metaphor, personification, hyperbole, Irony, metonymy, synecdoche, paradox, parable, repetition, symbol, antithesis, and oxymoron.
According to Perrine (in Arp, 2010:74), metaphor is figure of speech in which comparison is made between two things essentially unlike. The principal of metaphor is to compare two things unlike buthave same quality. Metaphor is compare two things directly without usea connective word such as like, as, if, etc. Metaphor use specific wordslike is, are, was, or were. Simile is A figure of speech of a comparison made between two objects of different kinds which have, however, at least one point in common,(Siswantoro, 2002: 24).

Hiperbole is used by the poet in an effort to describe the object, idea, etc. and to give weight excessively pressure toobtain an intense effect, (Siswantoro, 2002: 34). Acording to Pradopo (2000: 77), this figurative language is the use of an attribute of an object or use something closely connected with him to replace the object. An important part of a things (matter) to things or the thing itself, it is called synecdhoce (Pradopo, 2000: 78). This figure of speech is divided in two kinds: pras pro toto (part for whole) and totempras pro parpte (whole for part).Paradox is a figureof speechthat containsof the recall contradiction with the factsthat exist (Keraf, 2004:136). The irony will be successful if the listener is also 
aware of the literal meaning behind the series of words (Keraf, 2004:143). Parabel is a short story with human figures who always containmoral themes (Keraf, 2007: 140).

Repetition isa figure of speech that repeats a word or group of words several times ina different sentence. A symbol is a sign which refers to the object that denotes by virtue of a law, usually an association of general ideas, which operates to causethe symbol to be interpreted as referring to that object. (Pierce in Chandler,2007:39). Antithesis is a figure of speech which is conceived the charge of the opposition, the differences between the ideas expressed to each other and packed in one single sentence, (Siswantoro, 2002: 36-37).

Oxymoron comes from the language. Okys: "sharp" + moron: "crazy; foolish; stupid". Oxymoron is a style of language that attempts tocombine words to achieve conflicting effects. This style of language contains contradictions by using opposite words in the same phrase, because it has a dense and sharp nature of paradox (Keraf, 2007: 136).

Also in this research the writer only choose three selected poems of Robert Frost : "The Road Not Taken, My November
Guest, and Stopping By Woods On a Snowy Evening".Robert Frost is an American poet. He is born in San Francisco, California on March 26, 1874 - January 29, 1963. He is one of the great poets in America. In fact, poems deal with social human life and nature. In here, the writer uses Robert Frost ${ }^{\text {te }} \mathrm{s}$ poems because besides he is the greats poets, most of his poems have deep meaning and the figurative language gives poetic sense to his poem so the writer interested to discuss it. Also it can be a challenge for the writer to analyze that deep meaning. That is why to analyze the figurative language used in those poems are interesting.

Reasons why the writer choose to analyze this poems, because based on the observation and experience of the writer, most students in her college find difficulties when studying or reading poem. Any difficult vocabulary in it is either explained or given special attention such as meaning and symbol.

It is very important to understand about them because it will find theme and message. Theme is the main idea (subject matter) presented by the poet. All the work of literature must have a theme which is the principal issues raised in the written works 
of literature (Alfiah and Santoso 2009: 27).

Whereas message is a written spoken request, piece of information. We know what is the message conveyed by the author through his poem. So both of these elements are very important in a poem.

To know the similarity and the difference between this recent researchand previous research, here the writer has three previous researches :The first previous researcher is Niken Fajarwati (2016), the title is "An Analysis on Figurative Language Used inKaty Perry Seected Song". This research aims to find out the types of figurative language are found in Katy Perry's selected song, the frequency of the each type of figurative language found in Katy Perry selected song.The results of this study show that there were 21 simile, 5 metaphor, 4 personification, 13 hyperbole, 5 symbol, 21 idiom, 2 understatement, 3 rhetoric, 15 repetition, 1 onomatopoeia, 2 metonymy. While the percentage ofthe types of figurative language were $22 \%$ simile, $5 \%$ metaphor, $4 \%$ personification, $14 \%$ hyperbole, $5 \%$ symbol, $22 \%$ idiom, $2 \%$ understatement, $3 \%$ rhetoric, $16 \%$ repetition, $1 \%$ onomatopoeia, $2 \%$ metonymy.

The second previous researcher is Ichwan Setiawan (2017), the title is Symbols
In Robert Frost's Poems. His research aims to analysis the meaning of symbols in masterpieces of Robert Frost's poems, which focus on symbol which taking by symbol inpoem. He take the symbols which include in their poem. Three masterpiece of Robert Frost's poem are The Road not Taken, Fire and Ice, and Stopping bywoods on a snowy evening.The result of this study found that symbol can be seen in the poem, asin the poem the road not taken, the writer found that this poem describes aperson has two choices in life, and in the second poem Fire and Ice poem canbe note that the poem implies the symbols that represent way of life in whichthe life has spirit or fire to struggle, the third poem of Robert frost, the authorfound that a Stopping by woods on a snowy evening implies symbols that represent what kinds of spirits we struggle.

The third previous researcher is Octavia Ines Windyaswari (2018). The title is "Analysis on Figures of Speech in Emily Dickinson's: Because I Could NotStop for Death". Her research aims to discuss the figures of speech found in Emily Dickinson's: Because I Could Not Stop for Death. There are two research problems formulated, namely: 1) What figures of speech are found in "Because I Could Not 
Stop for Death" poem by Emily Dickinson? and 2)What is the meaning in each figure of speech found in "Because I Could NotStop for Death" by Emily Dickinson? The two research problems are approached using new criticism that has similarity with formalist. It is separated from external elements such as about the author"s life and history. The result in the research shows that there are four figures of speech, namely allegory, methapor, personification, and symbol. Those meanings offigures of speech tell that the poem is about the atmosphere felt by human beings when the day ends. The most frequently figure of speech found in the poem is symbol. It is a suggestion of other meaning than what it is. It can transfer the ideas embodied in the image without stating them. To draw the meaning, it needs to have critical thinking that is useful for language learning about figure of speech.

\section{METHOD}

As the qualitative research, it allows the writer to interpret the phenomenon which happens in the poem. This research uses library research with descriptive qualitative approach to analyze of Robert Frost's selected poems. This study attempts to provide answer of the research problems of the study in analyzing the figurative language of the poems, the meaning and the message used in the poems, and the theme of the poems. In line with the description above, the design is categorized into semantic content analysis.

The selected poem of Robert Frost becomes the primary data source, while the secondary data source is some previous research and other references that correlate with the topic of the research.

By using library research, the writer collects all the data then analyze the data by reading the selected poem, finding the figurative language, then identifying the most dominant figurative language used in the selected poem.

\section{DISCUSSION}

\section{The Road Not Taken}

First poem, "The Road Not Taken" is a poem by Robert Frost,published in 1916 as the first poem in the collection Mountain Interval. This poem published by Henry Holt and Company in New York.

\section{Poem 1: The Road Not Taken}

Two roads diverged in a yellow wood, And sorry I could not travel both And be one traveler, long I stood 
And looked down one as far as I could

To where it bent in the undergrowth;

Then took the other, as just as fair,

And having perhaps the better claim

Because it was grassy and wanted wear;

Though as for that the passing there

Had worn them really about the same,

And both that morning equally lay

In leaves no step had trodden black.

Oh, I marked the first for another day!

Yet knowing how way leads on to way

I doubted if I should ever come back.

I shall be telling this with a sigh

Somewhere ages and ages hence:

Two roads diverged in a wood, and I,

I took the one less traveled by,

And that has made all the difference

Table 1.1: The figurative language used in the first poem

\begin{tabular}{|l|l|}
\hline \multicolumn{1}{|c|}{ The poem } & \multicolumn{1}{|c|}{$\begin{array}{c}\text { Figurative } \\
\text { Language }\end{array}$} \\
\hline $\begin{array}{l}\text { Two roads diverged in } \\
\text { a yellow } \\
\text { wood }\end{array}$ & $\begin{array}{l}\text { Metaphor, } \\
\text { Symbol }\end{array}$ \\
\hline $\begin{array}{l}\text { And sorry I could not } \\
\text { travel both }\end{array}$ & - \\
\hline $\begin{array}{l}\text { And be one traveler, } \\
\text { long I stood }\end{array}$ & - \\
\hline
\end{tabular}

\begin{tabular}{|c|c|}
\hline $\begin{array}{l}\text { And looked down one } \\
\text { as far as I } \\
\text { could }\end{array}$ & - \\
\hline $\begin{array}{l}\text { To where it bent in } \\
\text { the } \\
\text { undergrowth }\end{array}$ & - \\
\hline $\begin{array}{l}\text { Then took the other, } \\
\text { as just as fair }\end{array}$ & - \\
\hline $\begin{array}{l}\text { And having perhaps } \\
\text { the better } \\
\text { claim }\end{array}$ & - \\
\hline $\begin{array}{l}\text { Because it was grassy } \\
\text { and wanted } \\
\text { wear }\end{array}$ & Personification \\
\hline $\begin{array}{l}\text { Though as for that the } \\
\text { passing } \\
\text { there }\end{array}$ & - \\
\hline $\begin{array}{l}\text { Had worn them really } \\
\text { about the } \\
\text { same }\end{array}$ & - \\
\hline $\begin{array}{l}\text { And both that } \\
\text { morning equally lay }\end{array}$ & Personification \\
\hline $\begin{array}{l}\text { In leaves no step had } \\
\text { trodden } \\
\text { black }\end{array}$ & - \\
\hline $\begin{array}{l}\text { Oh, I marked the first } \\
\text { for another } \\
\text { day }\end{array}$ & - \\
\hline $\begin{array}{l}\text { Yet knowing how } \\
\text { way leads on to }\end{array}$ & - \\
\hline
\end{tabular}




\begin{tabular}{|l|l|}
\hline way & \\
\hline I doubted if I should & \\
ever come & - \\
\hline back & \\
ages hence & - \\
\hline $\begin{array}{l}\text { Two roads diverged in } \\
\text { a wood, } \\
\text { and I }\end{array}$ & Metaphor \\
\hline $\begin{array}{l}\text { I took the one less } \\
\text { traveled by }\end{array}$ & - \\
\hline $\begin{array}{l}\text { And that has made all } \\
\text { the } \\
\text { difference }\end{array}$ & \\
\hline $\begin{array}{l}\text { Somewhere ages and } \\
\text { ages hence }\end{array}$ & - \\
\hline
\end{tabular}

From the table above, the writer found three types of figurative language, there are one symbol, two metaphor and two personification. So, the total are five figurative language.

In the poem The Road Not Taken, the writer found three types figurative language, there are one symbol, two metaphor, and two personification and the total are five figurative language. So, in this poem dominant "metaphor" and "personification".

\section{My November Guest}

The second poem is "My November Guest". My November Guestis taken from A Boy's Will, the first published volume of Robert Frostespoetry in 1913 by Henry Holt and Company in New York.

\section{Poem 2: My November Guest}

My Sorrow, when she ees here with me, Thinks these dark days of autumn rain Are beautiful as day can be;

She loves the bare, the withered tree; She walks the sodden pasture lane.

Her pleasure will not let me stay.

She talks and I am fain to list:

She ${ }^{e e}$ glad the birds are gone away, She se glad her simple worsted gray

Is silver now with clinging mist.

The desolate, deserted trees, The faded earth, the heavy sky, The beauties she so truly sees, She thinks I have no eye for these, And vexes me for reason why.

Not yesterday I learned to know

The love of bare November days

Before the coming of the snow, But it were vain to tell he so, And they are better for her praise 
Table2.1: The figurative language used in the second poem

\begin{tabular}{|c|c|}
\hline The poem & $\begin{array}{l}\text { Figurative } \\
\text { Language }\end{array}$ \\
\hline $\begin{array}{ll}\text { My Sorrow, when } \\
\text { she's } & \text { here } \\
\text { with me } & \end{array}$ & Personification \\
\hline $\begin{array}{l}\text { Thinks these dark } \\
\text { days } \\
\text { autumn rain }\end{array}$ & - \\
\hline $\begin{array}{l}\text { Are beautiful as day } \\
\text { can be }\end{array}$ & - \\
\hline $\begin{array}{l}\text { She loves the bare, } \\
\text { the withered } \\
\text { tree }\end{array}$ & Personification \\
\hline $\begin{array}{l}\text { She walks the } \\
\text { sodden pasture } \\
\text { lane }\end{array}$ & Personification \\
\hline $\begin{array}{l}\text { Her pleasure will not } \\
\text { let me stay }\end{array}$ & - \\
\hline $\begin{array}{l}\text { She talks and I am } \\
\text { fain to list }\end{array}$ & Personification \\
\hline $\begin{array}{l}\text { She's glad the birds } \\
\text { are gone } \\
\text { away }\end{array}$ & Personification \\
\hline $\begin{array}{lr}\text { She }{ }^{\text {ee }} \text { } & \text { glad } \quad \text { her } \\
\text { simple } & \text { worsted } \\
\text { gray } & \\
\end{array}$ & - \\
\hline $\begin{array}{l}\text { Is silver now with } \\
\text { clinging mist }\end{array}$ & Symbol \\
\hline
\end{tabular}

\begin{tabular}{|l|l|}
\hline $\begin{array}{l}\text { The desolate, } \\
\text { deserted trees }\end{array}$ & - \\
\hline $\begin{array}{l}\text { The faded earth, the } \\
\text { heavy sky }\end{array}$ & Hyperbole \\
\hline $\begin{array}{l}\text { The beauties she so } \\
\text { truly sees }\end{array}$ & - \\
\hline $\begin{array}{l}\text { She thinks I have no } \\
\text { eye } \\
\text { these }\end{array}$ & Personification \\
\hline $\begin{array}{l}\text { And vexes me for } \\
\text { reason why }\end{array}$ & - \\
\hline $\begin{array}{l}\text { Not yesterday I } \\
\text { learned to know }\end{array}$ & - \\
\hline $\begin{array}{l}\text { The love of bare } \\
\text { November } \\
\text { days }\end{array}$ & Symbol \\
\hline $\begin{array}{l}\text { Before the coming } \\
\text { of the snow }\end{array}$ & - \\
\hline $\begin{array}{l}\text { But it were vain to } \\
\text { tell her so }\end{array}$ & Personification \\
\hline $\begin{array}{l}\text { And they are better } \\
\text { for } \\
\text { praise }\end{array}$ \\
\hline
\end{tabular}

From the table above, the writer found three types of figurative language. There are seven personifications, two hyperboles, and two symbol. So, the totals are eleven figurative languages 
In this poem the writer found three types of figurative language. There is seven of personification, two of hyperbole, and two of symbol with the total are eleven figurative languages. So, in this poem, it dominant of "Personification".

\section{Stopping By Woods On a Snowy}

\section{Evening}

Third poem is "Stopping by Woods On a Snowy Evening”. This poem published in 1923 in the collection of New Hampshire. This poem published by Henry Holt and Company in New York.

\section{Poem 3: Stopping by Woods on a} Snowy Evening

Whose woods these are I think I know.

His house is in the village, though;

He will not see me stopping here

To watch his woods fill up with snow.

My little horse must think it queer

To stop without a farmhouse near

Between the woods and frozen lake

The darkest evening of the year.

He gives his harness bells a shake

To ask if there is some mistake.

The only other sound"s the sweep

Of easy wind and downy flake.

The woods are lovely, dark, and deep,

But I have promise to keep,
And miles to go before I sleep,

And miles to go before I sleep.

Table 3.1: The figurative language used in the third poem

\begin{tabular}{|l|l|}
\hline \multicolumn{1}{|c|}{ The poem } & \multicolumn{1}{c|}{$\begin{array}{c}\text { Figurative } \\
\text { Language }\end{array}$} \\
\hline $\begin{array}{l}\text { Whose woods these } \\
\text { are I think I } \\
\text { know }\end{array}$ & - \\
\hline $\begin{array}{l}\text { His house is in the } \\
\text { village, } \\
\text { though }\end{array}$ & - \\
\hline $\begin{array}{l}\text { He will not see me } \\
\text { stopping here }\end{array}$ & - \\
\hline $\begin{array}{l}\text { To watch his } \\
\text { woods fill up with } \\
\text { snow }\end{array}$ & Hyperbole \\
\hline $\begin{array}{l}\text { My little horse } \\
\text { must think it } \\
\text { queer }\end{array}$ & Personification \\
\hline $\begin{array}{l}\text { To stop without a } \\
\text { farmhouse } \\
\text { near }\end{array}$ & - \\
\hline $\begin{array}{l}\text { Between the woods } \\
\text { and frozen } \\
\text { lake }\end{array}$ & - \\
\hline $\begin{array}{l}\text { The darkest } \\
\text { evening of the year }\end{array}$ & - \\
\hline He gives his & - \\
\hline
\end{tabular}




\begin{tabular}{|l|l|}
\hline $\begin{array}{l}\text { harness bells a } \\
\text { shake }\end{array}$ & \\
\hline $\begin{array}{l}\text { To ask if there is } \\
\text { some mistake }\end{array}$ & - \\
\hline $\begin{array}{l}\text { The only other } \\
\text { sound }{ }^{\text {ee }} \text { the } \\
\text { sweep }\end{array}$ & - \\
\hline $\begin{array}{l}\text { Of easy wind and } \\
\text { downy flake }\end{array}$ & - \\
\hline $\begin{array}{l}\text { The woods are } \\
\text { lovely, dark, and } \\
\text { deep }\end{array}$ & Personification \\
\hline $\begin{array}{l}\text { But I have promise } \\
\text { to keep }\end{array}$ & - \\
\hline $\begin{array}{l}\text { And miles to go } \\
\text { before I sleep }\end{array}$ & Repetition \\
\hline $\begin{array}{l}\text { And miles to go } \\
\text { before I sleep }\end{array}$ & Symbol \\
\hline
\end{tabular}

figurative language. So, in this poem dominant of "Personification".

Table 4.1 Figurative language used in the selected poems

\begin{tabular}{|c|c|c|c|c|}
\hline $\mathrm{N}$ & $\begin{array}{l}\text { Title of } \\
\text { poem }\end{array}$ & $\begin{array}{c}\text { Figurati } \\
\text { ve } \\
\text { languag } \\
\text { e }\end{array}$ & $\begin{array}{c}\text { Num } \\
\text { ber } \\
\text { of } \\
\text { figur } \\
\text { ative } \\
\text { lang } \\
\text { uage }\end{array}$ & $\begin{array}{c}\text { Figurati } \\
\text { ve } \\
\text { Langua } \\
\text { ge } \\
\text { Domina } \\
\text { nt }\end{array}$ \\
\hline 1. & $\begin{array}{l}\text { The } \\
\text { RoadNot } \\
\text { Taken }\end{array}$ & $\begin{array}{l}\text { a. } \\
\text { Metaph } \\
\text { or } \\
\text { b. } \\
\text { Symbol } \\
\text { c. } \\
\text { Personi } \\
\text { fication }\end{array}$ & $\begin{array}{l}2 \\
1 \\
2\end{array}$ & \multirow{3}{*}{$\begin{array}{l}\text { Personi } \\
\text { fication }\end{array}$} \\
\hline 2. & $\begin{array}{l}\text { MyNovem } \\
\text { berGuest }\end{array}$ & $\begin{array}{l}\text { a. } \\
\text { Personi } \\
\text { fication } \\
\text { b. } \\
\text { Hyperb } \\
\text { ole } \\
\text { c. } \\
\text { Symbol }\end{array}$ & $\begin{array}{l}7 \\
2 \\
2\end{array}$ & \\
\hline 4. & $\begin{array}{l}\text { Stopping } \\
\text { byWoods }\end{array}$ & $\begin{array}{l}\text { a. } \\
\text { Hyperb }\end{array}$ & $\begin{array}{l}1 \\
1\end{array}$ & \\
\hline
\end{tabular}




\begin{tabular}{|l|l|l|l|l|}
\hline on & ole & 2 \\
aSnowyEv & b. & 1 & \\
& Syming & c. & & \\
& Personi & & \\
& fication & & \\
& Repetiti & & \\
& on & & \\
\hline
\end{tabular}

It shows that figurative language that use in the selected poems "The Road Not Taken", "My November Guest" and "Stopping by Woodson a Snowy Evening" there are "Metaphor, Personification, Simile, Symbol, Hyperbole, and Repetition". With the total of each, two Metaphors, eleven personifications, four symbols, three hyperboles, and one repetition. So, it can be occluded that this selected poems are dominate by "Personification".

\section{CONCLUSION}

Referring to the findings presented in the discussion, the figurative language of every poem is presented as the following:

1) The Road Not Taken: metaphor, symbol, and personification

2) My November Guest: personification, hyperbole, and symbol
3) Stopping by Woods on a Snowy Evening: hyperbole, symbol, personification, repetition.

The figurative language dominant is presented as the following: Total of figurative language in the selected poems are two Metaphor, eleven personification, four symbol, three hyperbole, and one repetition. So, it can be concluded that this selected poems are dominate by "Personification".

\section{REFERENCES}

Aqeel, Sajid, Shakir Et.Al, 2015. Stylistic Analysis Of Robert Frost's Poem Stopping By Woods On A Snowy Evening. International Journal of English And Education, Vol. 4, Issue 1, Pp. 504-512, January 2015.

Arp, Thomas. R. (2012). Perrine"s Sound and Sense: an introduction topoetry. Boson:United State Of Amerika.

Arya Surya Dharma, I Gede Yusma Pradita; Sadia, I Gde; Winaya, I Made. 2016.Figurative Language In Robert Frost's And William Wordsworth's Selected Poem. Denpasar : Udayana University

Damanhuri, M. 2011.Imagery and figurative language analysis on robert frost's poems to earthawrad and wind and 
Volume 2 Nomor 1 Juli 2021

window flower. Uin Syarif Hidayatullah Jakarta : Fakultas Adab dan Humaniora.

Dewangkari, Endah.2002. An Analysis On Figurative Language UsedIn John Donne's Poem. Unpublished.

Fajarwati, Niken. 2016. An Analysis on Figurative Language Used inKaty Perry Seected Song. Tulungagung. English Education Department.Faculty of Tarbiyah and TeacherTraining. State Islamic Institute (IAIN).

Gul Faraz Khan, Syeda Samar Shahid Bokhari.2020. Teaching Figurative Language through Poetry of Robert Frost at Graduation Level. University of Wah - Wah Cantt, Pakistan

Keraf, Gorys. 2004. Diksi dan Gaya Bahasa. Jakarta: Gramedia PustakaUtama.

mcGlinn,J. (2010). Poems by robert frost: a boy"s will and north ofbosthon. USA: Penguin Group(usa).

Mufidah, Mufidah. (2012). An Analysis of Figurative Language used in Robert Frost's poem. Skripsi : Tarbiyah dan Keguruan.

Pambudi, Rudy Tri and, Dr. Maryadi, M.A (2016) Figurative Language Used In Robert Frost's Poems. Skripsi thesis, Universitas Muhammadiyah Surakarta.

Pradopo, Rahmat Djoko. (2007). Pengajian Puisi. Yogyakarta: UniversityPress.

Sari, Melina. 2016 An Analysis of Figurative Language And Its Meaning In Robert Frost's Poems: Stopping By Woods On A Snowy Evening And The Road Not Taken. Skripsi : University of Lampung.

Setiawan, Ichwan. (2017). Symbols In RobertFrost"S Poems. Thesis. English Letters and Language Department, Faculty ofHumanities. The State Islamic University Maulana Malik Ibrahim of Malang.

Sudibyo, Gabriel Chamelia. 2019. Figurative Language Entry-Level Analysis On Robert Frost's A Minor Bird. Jurnal Kajian Sastra,Teater, dan Sinema.

Suwarso, Setyono Hardi. 2013. Figurative Language Used In "Acquainted With The Night" By Robert Frost Jurusan Sastra Inggris Fakultas Sastra Unud Windyaswari, Octavia Ines. (2018). Emily Dickinson's Because I CouldNot Stop for Death. Yogyakarta: Sanata Dharma University. 